\title{
Lived Experiences of Egyptian Female Juvenile Delinquents: Phenomenological Approach
}

\author{
Fatma M. Ahmed ${ }^{1}$, Amany S. Sorour ${ }^{1} \&$ Amal A. El Badawy ${ }^{2}$ \\ ${ }^{1}$ Faculty of Nursing, Zagazig University, Egypt \\ ${ }^{2}$ Faculty of Medicine, Zagazig University, Egypt \\ Correspondence: Fatma M. Ahmed, Faculty of Nursing, Zagazig University, Egypt. E mail: fmahmed@zu.edu.eg
}

Received: November 1, $2014 \quad$ Accepted: November 28, $2014 \quad$ Online Published: December 23, 2014

doi:10.5430/wjss.v2n1p51 URL: http://dx.doi.org/10.5430/wjss.v2n1p51

\begin{abstract}
Historically delinquency was considered the domain of boys, but recently female juvenile delinquents are a sizeable minority of the overall delinquent population, henceforth, current study aimed to explore the lived experiences of female juvenile delinquents in Egypt. A qualitative research approach was achieved by conducting focus group discussions with delinquent females and in-depth interviews with key workers from three residential correctional institutions in Egypt. Findings indicated that female juvenile delinquency is a multidimensional phenomenon resulting from stacking sets of strained relationships, community, \& individual triggering factors. Ultimately the crux of female juvenile delinquency is the family.
\end{abstract}

Keywords: lived experiences, female juvenile delinquency, phenomenology

\section{Introduction}

No one is born a good citizen; no nation is born a democracy. Rather, both are processes that continue to a lifetime. Former United Nations Secretary General, Kofi Annan (Gyampo, 2012). Living is a process of continual change. Infants become toddlers, pubescent children blossom into young men and women, and dependent adolescents develop into responsible adults (Eliopoulos, 2010). Children live, learn, and grow in an environment affected by ever-changing social, cultural, spiritual, and community factors (Kyle, 2008). Adolescence is a period of rapid physical, emotional, cognitive, and social growth and development. Generally, adolescence begins at age 11-12 years and ends between ages 18 and 21 (Kaplan \& Love-Osborne, 2005; Doherty et al., 2008). Adolescents experience hormonal changes, physical maturation, and, frequently, opportunities to engage in risk behaviors (United States Department of Health and Human Services, 2008).

Aggressive and violent behaviors are being increasingly viewed as a public health problem (Liu \& Wuerker, 2005). Antisocial behavior is a behavior that is harmful to others by breaking important social or moral norms. It includes aggressive and delinquent acts (Helmond et al., 2012). Juvenile delinquency is a critical problem that is becoming rampant in Egypt (Ahmed et al., 2012). Although, the exact number of juvenile delinquents is unknown, according to the Ministry of Interior Statistics; more than 25 percent of all arrested children in Egypt in 2001 were arrested on charges of being vulnerable to delinquency. However, their number has more doubled since 2000, rising from 17.228 arrests to 32.957 in 2008 (Fikry et al., 2012).

Juvenile delinquency describes the breaking of laws by youth. The age limit varies from country to country. The lower age limit is seven. It is believed that a child below 7 is Dolico-In Capax- that is incapable of committing crime, because the child cannot realize the consequences of his/her action. The upper limit varies between $16 \&$ 21year (Abraham, 2005). Delinquent behaviors range from engaging in status offenses to criminal and violent acts (Montgomery et al., 2011). Until recently, girls have been invisible in criminology studies and theories of delinquency. Hence, the increase in the arrest and detention of girls has brought more attention to the issue of female juvenile delinquency (Kelly, 2011).

Interpersonal environment (e.g. family and peers), physical environmental or community settings (e.g. schools), and societal (e.g. mass media, social and cultural norms) environment are important factors that contribute to the vulnerability of adolescents (Ghai et al., 2009). On the other hand; some children manage to achieve success despite 
the difficulties they encounter in life. This ability to positively adapt to negative situations is called resilience. These protective factors include support from a caring adult, Success in school, school connectedness, and religiosity (Zahn et al., 2008).

A team approach is necessary in management of juvenile delinquency including social workers, psychologists, psychiatrists, pediatricians, community health nurse, schoolteachers, family members and parents (Datta, 2009). Residential institutions provide unique settings for the community health nurse to practice health promotion, clients are more accessible, their needs can be readily assessed, and their interests can be stimulated (allender et al., 2013). Increased justice system involvement among girls and current portrayals of girls in the local media and press suggest steadily exacerbating problem that generate a crisis to the extent of affecting social security. Hence, this study aims to explore the lived experiences of female juvenile delinquents.

\section{Participants and Methods}

\subsection{Design}

Using a qualitative approach added personal descriptions in context and individual voices, which verified how the nature of relationships are very complicated and can involve many harmful aspects that put adolescent girls at risk for delinquent behavior. Hence, a phenomenological approach was used to conduct the existing study.

\subsection{Informants}

Because the goal of qualitative research is enriching the understanding of an experience, it needs to select fertile exemplars of the experience for study (Polkinghorne, 2005). Henceforth, the informants were juvenile delinquent females $(n=24)$, and for complete description of the scene, the experiments of 16 key workers were taken into consideration (manager [ $\mathrm{n}=3]$, psychiatrist [ $\mathrm{n}=3]$, social specialist $[\mathrm{n}=5]$, and supervisor $[\mathrm{n}=5]$ ).

\subsection{Setting}

The current study was conducted in three females' residential correctional institutions affiliated to the Ministry of Solidarity \& Social justice. They were namely; Fatyat El Mansoura - Dakahlia, Elmolahza department in Dar El Tarbeya- Giza, and Quaserat Ain Shams - Cairo. The letter of approval was approved from security department Ministry of Solidarity \& Social justice, and the final letter of authorization was granted from the General Directorate of Social Defense, but with a condition of not video or audio tapping, and not reviewing girls' records, hence there was extra burden on the researcher (facilitator) and the assistant to be more attentive in note taking. Data collection occurred over a three month period (end of January to the beginning of May 2012).

\subsection{Recruitment}

Participants recruited to take part in discussion by each institution manager (it was her responsibility to ask them about their opinion to take part in the study). Data collection continued until no new themes emerged from the interviews; the sample size was determined by completeness of data.

\subsection{Interviews}

Qualitative researchers use various methods of data collection including key-informant interviews, focused group interviews, and structured questionnaires. Key-information interviews are relatively unstructured informal interactions with knowledgeable stakeholders who can provide general information about the context, population, or culture (Nastasi \& Schensul, 2005). Each in-depth interview lasted approximately $1 / 2$ to 1 hour, depending on the degree of detail each interviewee contributed. It was confirmed that the interview is for a research study that is being done to gather information on the lived experiences of female juvenile delinquents.

Focus groups are valuable because they enable participants to "speak in their own voice" and "to express their own thoughts and feelings", (Moloney, 2010). A 1 to 2 hour discussion completed over 8 focus groups. Each focus group contained 3 participants (mini focus group), as far as possible from the same friendship groupings to encourage openness and honesty.

The sessions started with a brief introduction about the aim of the interview and an ice-breaker activity to make participants ready to engage in the discussion. Participants were told there were no wrong answers and that research results will be anonymous. Probe questions were used to take the discussion into still deeper territory, "Please tell me more about that" or "I do not think I know what you mean, can you explain?". In an effort to obtain detailed responses, the researcher responded to the interviewee by utilizing active listening and silence to distill their responses. 
Topic guides were prepared beforehand; topics for discussion were introduced in an open and informal style, to allow the participants bring up their opinions. The common domains discussed in the focus group were: relationships within family, neighborhood, school, work, and with peers; and the story behind being instituted. Whereas, in-depth interview areas were, the prevalence \& characteristics of female juvenile delinquents, role of (family, school, and friends), and surrounding factors (abuse, child labor, and media).

\subsection{Ethics}

For the purpose of the present study oral informed consent was obligatory, on the one side to keep secrecy of participants, and on the other side the researcher was not allowed to take any data from girls' files as conditioned in the permissions, alias were used instead, participation was voluntary, and there was no penalty for refusing to participate.

\subsection{Analysis}

On gathering the data, a permanent written record of the discussions (Transcription) was established to facilitate further analysis. Data was coded and categorized; then, the researcher spent much time reading and re-reading transcripts searching for a pattern. Next, ongoing comparison of the participants' responses with each other was performed. After that, the data were subjected to a thematic analysis (the extraction of the common themes emerging from the interviews). Finally, the emergent themes were revised many times.

\section{Results}

\subsection{Baseline Data}

Although the real lived stories of the participants were different, it crisscrossed in certain points \& shared the keywords which described the end of each story, and the same fate.

Table 1. Current study participants' profile

\begin{tabular}{|c|c|c|c|c|c|}
\hline Alias & Age & Residence & Educational level & $\begin{array}{c}\text { Marital } \\
\text { status }\end{array}$ & $\begin{array}{l}\text { Type of } \\
\text { sentence }\end{array}$ \\
\hline Eve (1)* & 18 yrs. & Urban & $4^{\text {th }}$ primary & Divorced & Robbery \\
\hline Eve (2) & $15 \mathrm{yrs}$. & Rural & $3^{\text {rd }}$ prep & Single & Murder \\
\hline Eve (3) & $13 \mathrm{yrs}$. & Urban & $6^{\text {th }}$ primary & Single & Murder \\
\hline Eve (4) & $17 \mathrm{yrs}$. & Urban & $1^{\text {st }}$ secondary & $\begin{array}{l}\text { Customary } \\
\text { marriage }\end{array}$ & Robbery \\
\hline Eve (5) & $17 \mathrm{yrs}$. & Urban & $3^{\text {rd }}$ prep & Single & Theft \\
\hline Eve (6) & $18 \mathrm{yrs}$. & Urban & $2^{\text {nd }}$ primary & Single & theft \\
\hline Eve (7) & $18 \mathrm{yrs}$. & Urban & $1^{\text {st }}$ primary & Divorced & Prostitution \\
\hline Eve (8) & 19 yrs. & Urban & Illiterate & $\begin{array}{l}\text { Not married } \\
\text { not virgin }\end{array}$ & Prostitution \\
\hline Eve (9) & $18 \mathrm{yrs}$. & Urban & $3^{\text {rd }}$ primary & Divorced & Prostitution \\
\hline Salma & $19 \mathrm{yrs}$. & Urban & $5^{\text {th }}$ primary & Divorced & Prostitution \\
\hline Jana & $17 \mathrm{yrs}$. & Urban & $3^{\text {rd }}$ prep & $\begin{array}{l}\text { Not married } \\
\text { not virgin }\end{array}$ & Prostitution \\
\hline Eve (10) & 20 yrs. & Urban & $4^{\text {th }}$ primary & $\begin{array}{l}\text { Customary } \\
\text { marriage }\end{array}$ & Prostitution \\
\hline Eve (11) & $14 \mathrm{yrs}$. & Rural & $2^{\text {nd }}$ prep & Single & Murder \\
\hline Haneen & $18 \mathrm{yrs}$. & Urban & $2^{\text {nd }}$ prep & Single & $\begin{array}{l}\text { Resistance of } \\
\text { authorities }\end{array}$ \\
\hline Malak & 14 yrs. & Rural & $1^{\text {st }}$ prep & $\begin{array}{l}\text { Not married } \\
\text { not virgin }\end{array}$ & Murder \\
\hline Shakawa & $15 \mathrm{yrs}$. & Urban & $6^{\text {th }}$ primary & $\begin{array}{l}\text { Customary } \\
\text { marriage }\end{array}$ & Robbery \\
\hline Gharam & 16 yrs. & Urban & $5^{\text {th }}$ primary & $\begin{array}{l}\text { Customary } \\
\text { marriage }\end{array}$ & $\begin{array}{l}\text { Robbery \& } \\
\text { attempted } \\
\text { murder }\end{array}$ \\
\hline Eve (12) & 18 yrs. & Rural & $1^{\text {st }}$ prep & Widowed & Murder \\
\hline
\end{tabular}




\begin{tabular}{|llllll} 
Eve (13) & 16.5 yrs. & Urban & $4^{\text {th }}$ primary & Divorced & Robbery \\
Eve (14) & 17.5 yrs. & Urban & 2 primary & Single & Robbery \\
Eve (15) & 17.5 yrs. & Urban & 1 prep & Married & Robbery \\
Eve $(16)$ & 19 yrs. & Urban & $3^{\text {rd }}$ primary & Married & Murder \\
Eve $(17)$ & 19 yrs. & Urban & Illiterate & Single & Theft \\
Eve (18) & 20 yrs. & Urban & $3^{\text {rd }}$ faculty & Single & Murder
\end{tabular}

*Eve was a pseudonym used for those girls who preferred to participate in the focus group discussion with their real name.

As shown in table 1, regarding delinquent females' profile, their age ranged from 13 to 20 years, 20 out of 24 were from urban areas. With regard to education, 2 girls were illiterate while 17 girls dropped out from education (mainly primary education). Related to marital status, only 9 were single. As to the top reasons of institutionalization, murder was the dominant sentence followed by prostitution and robbery; consequently, the current study participants' crimes can be rated as violent crimes (serious offenses).

\subsection{Emergent Themes and Subthemes}

Following data analysis, six core themes, interpreting the lived experiences of female juvenile delinquents emerged, the relationship between these themes were portrayed in the flow chart:

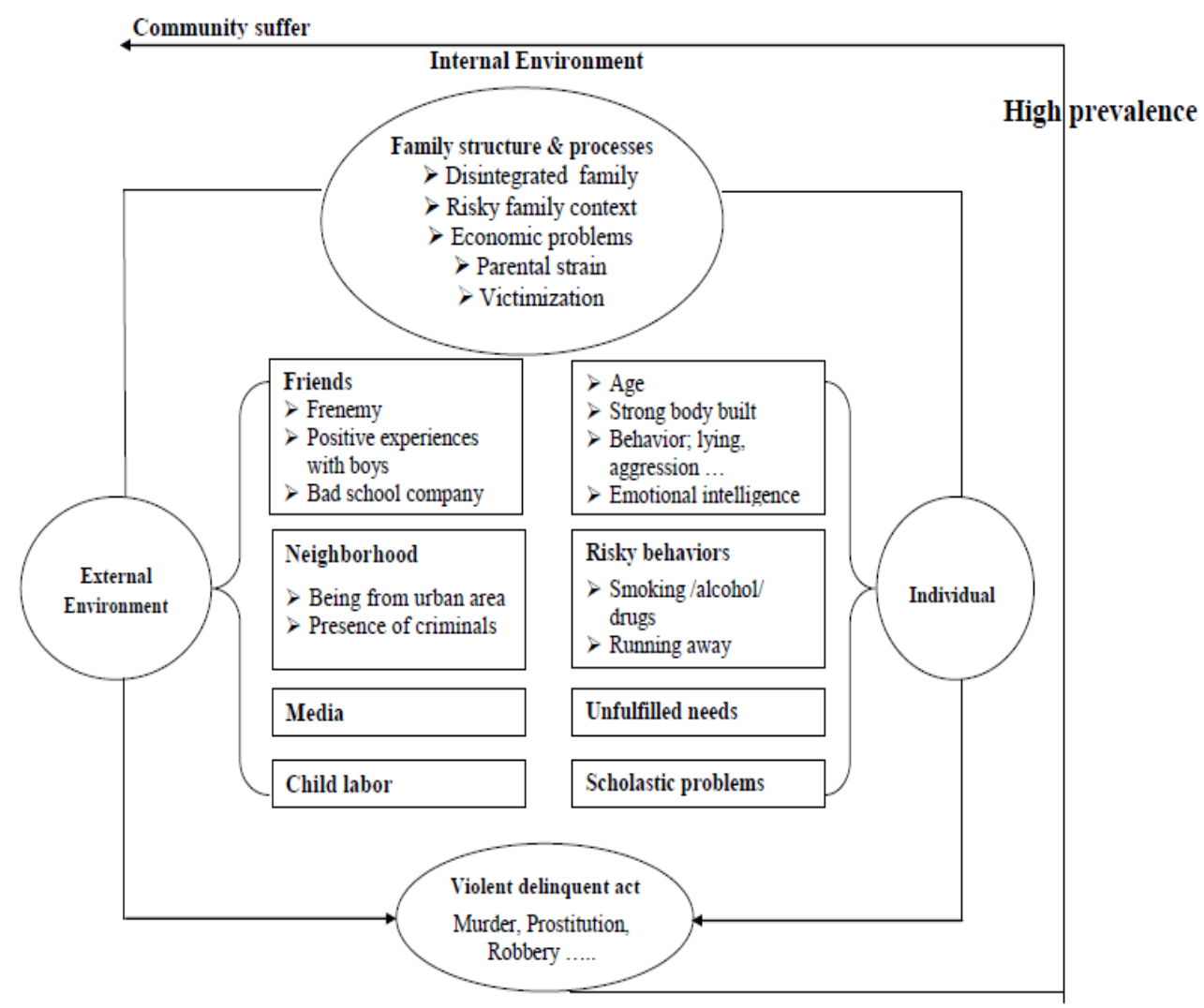

Figure 1. Female juvenile delinquency status \& processes flow chart

\subsubsection{Relationship Strain}

Girls often place much value on their relationship with others. Girls who experience jeopardized and/or negative familial and peer relationships often resort to delinquent behaviors (Snethen \& Puymbroeck, 2008). Families strained the lives of their daughters by separating from them, either because father traveling abroad for work or father is present, but there is harsh discipline; intra-familial conflict which in turn equipped girls to resort to friend for soothing their hard times or search for help from family member or relative other than father or mother. 
"I never had a chance to talk with my mother. I wish I had been her friend. Whenever I complained to her, she told my uncles. My mother doesn't worth to be a friend. My colleagues were young, yet they know"

In other words disintegrated family life where there is absent or incomplete monitoring of girl, lost sense of belongingness \& affection, and hence searches for it elsewhere. Besides risky family context (deviance supportive family); poverty forced the family to depend on the girl as a source of income, and the greediness of families which consider their girls commodities for sale.

"The father makes his daughter take drugs and friend guys and go with them to their flats. The daughter sees her mother unfaithful to her father or be a thief " Key worker

"Family makes the girl go outside and do anything for money. Husband (sell) her to Arabic person for money (fixed term marriage)" Key worker

Many crime theorists believe that victimization breeds later delinquency. To view these females as victims is justifiable, the current study participants experienced different forms of abuse (physically, emotionally, or incest) at home.

"My father was cruel, he always beat me with the gas pipe or the umbrella stick, and he used to lift me and dropped me to the ground. He always said bad words against me. I fed up with our home that made me escape from home"

"My father obliged me to marry a man 45 years old when I was still 17. After only 15 days, I couldn't put up with him, so I poisoned him"

Negative life events as parent divorce, father's death, and losing mentor were reported by delinquent girls as different forms of loss. Considering that human beings are social animals seek the belongingness and companionship, and that the family is the primary social institution, any loss or deprivation at the family level is hard to be compensated especially if the family members or caretakers are not qualified to take the mentor role. Hence, the kid can deviate from the normal track easily.

"I used to tell everything to my older sister. But when she died, I had no one to tell him, but I used to talk to a mirror, it only listened but didn't answer. That was better than my friends made fun of me"

"The most memorable bad day in my life was the day my father dead"

The relationship between friends and delinquent behavior is one of the most debated issues. Friend is a person attached to another by feelings of affection or personal regard. Negative relationships are sometimes called "toxic relationships", while others call it "frenemy". The term Frenemy comes from merging the words friend and enemy. The current study participants described their friend as being bad, while others had no friends or not trusting them because they encouraged them to run away from home, to be like them and exhibit the same path, or taught them risk taking behaviors, being a victim of friend was also most prominent.

"Each time I made friend with a girl, I discover that she is not good. She stands beside me when she needs something. All I made friends with aren't trusted. My friend made me know boys, and had money from them. Later I realized that I lost everything then, I went to bars and casinos"

\subsubsection{Education/ School Problems}

Although they loved school, those girls had poor academic performance either because they didn't have academic aspiration, or they didn't have teacher understanding their learning difficulties; truancy \& low bonding to school; bad company in school context; and being marginally literate because of dropping out mainly from elementary education were also most notable.

"I wasn't good at school. From time to time, teachers beat me. I never met anyone who made me feel that I wanted to complete education"

"I dropped out from $2^{\text {nd }}$ primary school. We had a shop, my father made me run it. I was afraid of him, but I was always angry. I feel a pity when my friends go to school"

\subsubsection{Community/ Neighborhood}

Being from urban area which might have many sources of risk as being densely populated, disrupted, low degree of social cohesion, which in turn can be identified by low social control and weak social networks, and hence inhabitants are less likely to be discouraged from delinquent behavior. The presence of criminals can directly or indirectly affect the normal course of living and norms of any society, and give a vivid example of devil which can 
attract others to its world.

"Very ordinary people, neither rich, nor poor, when I wanted to join the market of human beings, I found it wrong. I get up at night and sleep by day. All people hate each other. Once I am standing in a street, I see someone having drug without being afraid, he may attack any girl. You may be a sleep, and someone cries, that man was in that woman's flat, or you hear firebombing"

Child labor either because they were compelled to work (by family), or to help the family. Those girls can meet bad persons, or are able to gain money at a very young age, this gives them a sense of independence so they are not in need for family, and they can do whatever they want.

"Work is not good for girls. The girl faces bad things. She may know bad people. Most of my friends worked and were ready to sell themselves at any price"

Over different types of media, television received the lion's share, where it's content encourage imitation, and spreading immorality.

"Love of imitation and excitement in Arabic and foreign films; Television is the most serious thing, now its role is to spread ill-bred, it has a passive role. Even TV serials are trifle and wearing clothes that is not good"

\subsubsection{Risk Behaviors}

Smoking /alcohol/ drugs, these habits were mainly accustomed from friends, or through family members. The relation between these health-compromising behaviors and delinquency is bidirectional, but which one provokes the other needs more elaborated researches. Running away was more common among abused girls. The girls' reaction to varied forms of maltreatment or strained family relationships tend to accumulate and escalate over time to end in unwise decisions.

"Cigarettes, made friends with guys who gave me drugs, tablets, injections, and powder"

\subsubsection{Profiling Delinquent Girls (Trigger factors)}

Being adolescent, usually girls tend to spend more time at home, under their parents' supervision, and less exposed to neighborhood structural and social factors at least until early adolescence. In relation to the physical characteristics, key workers believe that these girls tend to be in fit physical appearance to help them in their delinquent acts, while others see that they are physically fit because of living in the gang world. Being lyres, aggressive, and having stealing abilities were on the top of the behavioral characteristics profiling delinquent females. The cause behind lying might be attributed to escaping punishment, obtaining reward, to cover for peers, or because of the lost sense of trust, it also can be used as a cover for other delinquent behaviors as stealing; by the time the child can use an overt behavior as aggression instead of lying.

"They are used to lying, they are thieves, and they used to take anything even if it is a pen, then break and throw it. They used to take everything without losing anything" Key worker

Belongingness, love \& affection needs were the most highlighted past needs as conveyed by juvenile females, whereas on the social aspect emotional intelligence was the dominant.

"I wish my father and mother had lived together. They should have been kind to me. Since there is no mercy in life, no one can live"

"Social intelligence is very high. They know how to reach their goals very well, only in bad things" Key worker

\subsubsection{Protective Factors}

Albeit loving school, and presence of good people in the neighborhood context, these protective factors was not strong enough to refrain girls from being delinquents, this might be attributed to that the other risk factors were more influential (family \& friends).

"I used to love school. I didn't want Friday to come so that I wouldn't stay at home"

"People were very merciful, they loved each other. On feast days they buy meat, and in Mawld El. Naby (the birth of the prophet Mohammed day) sweets, may father wasn't rich. They loved me, I left home but when I came back they advised me and I loved them"

To end with the main cause behind female juvenile delinquency, the delinquent girls' answers excelled mainly in charging either parents or one of them, then themselves. Those females who blamed themselves said that with a sense of remorse about their impulsivity (acting before thinking), not seeking adult advice, or bad company. 
"I blame myself. I should have asked who are older than me. I'm sure they would have helped me"

Moreover, all the key workers see that family is the main cause; their rationale for accusing the family was abused, disintegrated family, and absence of monitoring \& modeling, and belongingness. Finally, it can be said that the whole burden of bringing up good citizens is the responsibility of the family.

"Parents are the main cause, a girl who imitates her mother. Making girls marry at an early age is like a man who gets married to a girl who doesn't want to marry him" Key worker

\section{Discussion}

Qualitative research methods have given the delinquent females the opportunity to tell their stories, and the opportunity to researcher to extract the essence of the female juvenile delinquency to determine the influential factors.

Female juvenile delinquency is a troublesome problem, as female juvenile delinquents are harming society as a whole; in a similar vein other researches confirmed that the society will suffer from the consequences of delinquents' antisocial attitude (Ou \& Reynolds, 2010). Regarding the reasons of institutionalization, all the current study crimes rated as violent where murder was the dominant crime. On the contrary, other studies found that none of the girls reported murder (Fikry et al., 2012), and females not only commit fewer offences, but also commit less serious offences (Steketee et al., 2013). This discrepancy might be attributed to the discrimination between males and females, and the repeated feminine calls for equality between women and men in the last years created a new generation who is trying to imitate men in many things even violent crimes.

General strain theory is a social-psychological theory that explains delinquency as a response to negative emotions elicited by adverse experiences and relationships (Hollist et al., 2009). Relationship strain explains the majority of girls' delinquent behavior, where major types of relationship strain are familial strain, and frenemy strain (Garcia \& Lane, 2012). Criminal victimization identified as among the types of strain that are most likely to lead to delinquency (Hay \& Evans, 2006).

Concerning familial strain, the current study participants had deficient / destructive family lives where the source of the deficiency is: family structure, youngsters not living with two of their (biological) parents showed more delinquent behavior than adolescents who are living with both of their parents (Weijters et al., 2009); disintegrated family life, when the family was disrupted, females were more likely to engage in delinquent behavior (Hollist et al., 2009); risky context, parental deviance, drug abuse, and family criminality are significant in the development of delinquency in adolescents (Kelly, 2011); parental strain, when problems in the parent-child relationship increase the void that is left in the absence of a healthy bond may be filled with associations conducive to attitudes and values favorable to delinquency (Garcia \& Lane, 2012); and economic problems, many findings indicate that the spatial distribution of crime is linked with the amount of poverty within an area, so the higher the level of economic deprivation, the higher the level of delinquency and crime (Trogdon, 2006).

Many crime theorists believe that victimization breeds later delinquency. Half of delinquent girls participated in the current study experienced different forms of abuse (physically, emotionally, or sexually) at home. Harmoniously, having experienced intra-familial violence Egyptian females were at slightly greater risk than their male counterparts (Rivera-Rivera et al., 2005). Females who engage in antisocial or delinquent juvenile behavior are more likely to have histories of abuse and victimization within the family environment (Grande et al., 2012). The daily struggles began in homes, the institution that should have provided love, care, nurture, and support became a place of hate, abuse, and neglect for most of the girls (Aulakh, 2008). Research indicates that adverse life events, especially physical or sexual abuse, are stronger predictors of serious offending in girls (Borduin \& Ronis, 2012). In addition, losing a loved one can be considered as a negative life event, that loss or deprivation at the family level is hard to be compensated, especially if the family members/care takers are not qualified to take the mentor role.

As for frenemy strain, the current study results revealed a different view about the meaning of friendship where the majority of key workers believed that bad friends play a role in their counterparts' delinquency, and the delinquent females' responses insisted on conveying negative feedback about their friends. In the same vein a study results confirmed that $46 \%$ of the youth described their friends as being primarily negative (Tankersley, 2006). In addition, a research study revealed that, participants reported turning to their peers for support, safety, and acceptance. The peers that each participant was associated with were already participating in delinquent activities, which increased their motivation to partake in delinquent activities as well (Kruger, 2009). Moreover, being in groups that are involved in nuisance behavior leads to delinquent behavior more often in females (Steketee et al., 2013). 
The school features that were shown to be risk factors for delinquent behavior among adolescent females included: academic problems, investigators have reported that delinquent girls demonstrate poorer academic performance than do non-delinquent girls (Borduin \& Ronis, 2012); low bonding to school \& truancy, youth who fail to complete school and those who are frequently truants are, in turn, at increased risk for delinquency (Bender, 2010). Furthermore, adolescents reporting poor school bonding display more problem behaviors such as delinquency (Liljeberg et al., 2011); bad company, the confluence of low emotional connectedness with school coupled with association with delinquent peers is likely to result in initiation of and continued involvement in delinquency (Li et al., 2011); and dropping out of school, the importance of school failure in the development of delinquency figures much larger in the lives of girls. Additionally, girls are 7 times more likely to drop out of school for family purposes (Weijters et al., 2009).

The risk factors cited at the community level for development of delinquent behavior among female included: urban versus rural residence, the problem of juvenile delinquency particularly in urban areas has grown significantly in recent years (Ekpenyong et al., 2012); presence of criminals, some girls reported that they or their families perceived their neighborhoods as so full of dangerous people, places, or situations (Molnar et al., 2005). In addition, youngsters who live in disorganized neighborhoods are more likely to become delinquents (Alanezi, 2010); child labor, working children can gain a false sense of their ability to provide for themselves that encourages them to risk leaving a family environment that they consider unsatisfactory (Human Rights Watch, 2003); and media, the media can indirectly lead people to choose violence. Television, movies, newspapers, and magazines show happy, fun-loving people. Television parades all the wonders money can provide. Frustration, unfilled dreams, and unmet wishes are often handled through hunting someone who cannot fight back (Mathre, 2006).

Risk-taking refers to the tendency to engage in behaviors that have the potential to be harmful or dangerous. In this context, the current study revealed that juvenile delinquency tend to co-occur commonly among females who smoke/using alcohol/drugs, in the same context, researches revealed that a number of health-compromising behaviors such as smoking, drinking, and substance use might become prominent among many adolescents. A substantial body of literature has suggested that delinquency and health-compromising behaviors are closely linked (Li et al., 2011), and those who have run away from their home, when girls were faced with familial strain they tended to cope by using drugs, or running away from home (Garcia \& Lane, 2012).

Many etiological factors can trigger juvenile delinquency, in the current study certain personality profiles appeared to be associated with delinquency they are: age, as children mature they receive less supervision, particularly females. In society, females remain under parental supervision for a longer period than males, therefore with the onset of adolescence, there is a level of newfound freedom (Martin, 2008); physically, where those girls tend to be in fit physical appearance, helping them in their delinquent acts, or because of living in a gang world; behaviorally, female juvenile offenders display significant amounts of both physical and relational aggression, behaviors that are related to concurrent and future internalizing and externalizing problems in girls (Goldstein et al., 2013); psychologically, the gang seemed to be a reasonable solution to their significant and variety of problems (Aulakh, 2008). In the same context, the sense of belonging is considered a symbolic attachment or investment to a place in terms of a feeling of "rootedness or centeredness". Researches show that it is important for children to "feel at home" when they are between nine and eleven years old (Ünlü et al., 2010); and socially, on the contrary other researches revealed that, self-management of the emotions was negatively associated with all types of problem behavior. Lower levels of trait emotional intelligence are associated with higher levels of such externalizing behavior as aggression and delinquency (Siu, 2009).

Consistent with the results of the current study about the main causes behind female juvenile delinquency Foley (2008) confirmed that, surveys and focus groups with justice-involved girls and their staff and administrators, family problems were the top risk factor for girls' delinquency, followed by individual problems, peer issues, and school and community factors, respectively. Furthermore, Church II et al. (2012) indicated that, the critical role the family plays in juvenile delinquency has been said to be the single most replicated finding in the juvenile deviance literature.

\section{Conclusion}

Female juvenile delinquency phenomenon begins to color the world of females aged 7 to 18 years, where murder is ranked as the top of committed crimes. Risk factors associated with female juvenile delinquency are multifaceted \& interrelated. Denouement of female juvenile delinquency phenomenon can be simply illustrated in one sentence "not done deeds and unmet needs". 


\section{Recommendations}

To tackle female juvenile delinquency the root causes of crime must be addressed, not the act itself. Hereafter, the current study recommends launching community-based programs to respond to the special needs of girls by offering appropriate counseling and guidance; family-based programs to support the role of parents as socialization agents in the lives of their girls; Adopting the human capital perspective (investment of resources to increase the social, emotional, and educational skills of girls) as a management modality; Ultimately, the study be expanded quantitatively to permit for generalization.

\section{References}

Abraham, C. M. (2005). Sociology for nurses: A textbook for nurses and other medical practitioners. India: B.I. Publications PVT. LTD. pp. 23, 236.

Ahmed, A., Sadek, M. N., Amer, D., \& Fathy, H. (2012). Addictive profile in juvenile delinquents admitted to correctional institutions in relation to personality characteristics. Middle East Current Psychiatry, 19(2), 78-84.

Alanezi, F. (2010). Juvenile Delinquency in Kuwait: Applying Social Disorganization Theory. Digest of Middle East Studies, 19(1), 68-81.

Allender, J., Rector, C., \& Warner, K. (2013). Community Health Nursing: Promoting the Public's Health (8 ${ }^{\text {th }}$ ed).China: Wolters Kluwer Lippincott Williams \& Wilkins. p. 67.

Aulakh, H. K. (2008). The social and legal context of female youth crime: A study of girls in gang. Published thesis, college of graduate studies and research, University of Saskatchewan, Canada. pp. 177, 188, and 193.

Bender, K. (2010). Why do some maltreated youth become juvenile offenders? A call for further investigation and adaptation of youth services. Children and Youth Services Review, 32, 466-473. http://dx.doi.org/10.1016/j.childyouth.2009.10.022

Borduin, C. M., \& Ronis, S. T. (2012). Research Note: Individual, Family, Peer, and Academic Characteristics of Female Serious Juvenile Offenders. Youth Violence and Juvenile Justice, 10(4), 386-400.

Church II, W. T., Tomek, S., Bolland, K. A., Hooper, L. M., Jaggers, J., \& Bolland, J. M. (2012). A longitudinal examination of predictors of delinquency: An analysis of data from the Mobile Youth Survey. Children and Youth Services Review, 34(12), 2400-2408. http://dx.doi.org/10.1016/j.childyouth.2012.09.007

Datta, P. (2009). Pediatric Nursing (2nd ed). New Delhi: Jaypee Brothers Medical Publishers (P) LTD. Behavioral Disorders in Children. p. 193.

Doherty, E. E., Green, K. M., \& Ensminger, M. E. (2008). Investigating the long-term influence of adolescent delinquency on drug use initiation. Drug and Alcohol Dependence, 93, 72-84.

Ekpenyong, N. S., Lasisi, R., \& Ekpenyong, A. S. (2012). Urban Poverty and Juvenile Delinquency in Nigeria: Through the Lens of Port Harcourt Remand Home Inmates. Research on Humanities and Social Sciences, 2(8), 127-132.

Eliopoulos, Ch. (2010). Gerontological Nursing ( $7^{\text {th }}$ ed). Ch 4. China: Wolters Kluwer Health | Lippincott Williams \& Wilkins. pp. 35 and 50.

Fikry, F., Oueda, M.A., Abo Nazel, M.W., Ahmed, A., \& Abed El.Hakim, R. (2012). The effect of Cognitive Behavioral Therapy on Behaviors of Juvenile Delinquents Resident in Correctional Institutions in Alexandria. Journal of American Science, 8(2), 255-264.

Foley, A. (2008). The current state of gender-specific delinquency programming. Journal of Criminal Justice, 36(3), 262-269. http://dx.doi.org/10.1016/j.jcrimjus.2008.04.007

Garcia, C. A., \& Lane, J. (2012). Dealing with the fall-Out: Identifying and addressing the role that relationship strain plays in the lives of girls in the juvenile justice system. Journal of Criminal Justice, 40(3), 259-267. http://dx.doi.org/10.1016/j.jcrimjus.2012.02.005

Ghai, O., Paul, V. K., \& Bagga, A. (2009). Essential Pediatrics $\left(7^{\text {th }}\right.$ ed). India: CBS Publishers \& Distributors PVT LTD. pp 42-43.

Goldstein, N. E. Serico, J. M., Riggs Romaine, C. L., Zelechoski, A. D., Kalbeitzer, R. Kemp, K., et al. (2013). Development of the Juvenile Justice Anger Management Treatment for Girls. Cognitive and Behavioral 
Practice, 20(2), 171-188.

Grande, T. L., Hallman, J. M., Underwood, L. A., Warren, K. M., \& Rehfuss, M. (2012). Treating Detained Juveniles: Measuring Mental Health Traits and Gender Differences. Review of European Studies, 4(5), 14-23.

Gyampo, R. (2012). The Youth And Development Planning In West Africa: The Case Of Ghana's Fourth Republic. African Journal of Social Sciences, 2(1), 130-146.

Hay, C., \& Evans, M. M. (2006). Violent victimization and involvement in delinquency: Examining predictions from general strain theory. Journal of Criminal Justice, 34(3), 261-274. http://dx.doi.org/10.1016/j.jcrimjus.2006.03.005

Helmond, P., Overbeek, G., \& Brugman, D. (2012). Program integrity and effectiveness of a cognitive behavioral intervention for incarcerated youth on cognitive distortions, social skills, and moral development. Children and Youth Services Review, 34(9), 1720-1728. http://dx.doi.org/10.1016/j.childyouth.2012.05.001

Hollist, D. R., Hughes, L. A., \& Schaible, L. M. (2009). Adolescent maltreatment, negative emotion, and delinquency: An assessment of general strain theory and family-based strain. Journal of Criminal Justice, 37, 379-387. http://dx.doi.org/10.1016/j.jcrimjus.2009.06.005

Human Rights Watch. (2003). Egypt: Charged with Being Children: Egyptian Police Abuse of Children in Need of Protection, 15(1), 1-79.

Kaplan, D. W., \& Love-Osborne, K. (2005). Adolescence. In Hay, W. W., Levin, M. J., Sondheimer, J. M., \& Deterding, R. R. (ed.) Current Pediatric Diagnosis \& Treatment (17th ed). USA: McGraw-Hill Companies, Inc. pp. 102, 113.

Kelly, A. (2011). Predictive Factors of Female Juvenile Delinquency. Published dissertation, School of Education, faculty of Trevecca Nazarene University, USA. pp. 1-4, 162.

Kruger, H. A. (2009). Exploring a Delinquent Past: Women's Experiences as Adolescents Involved in Delinquent Activities. Published thesis, College of Graduate Studies and research, University of Saskatchewan, Saskatoon. pp. 5, and 67-68.

Kyle, T. (2008). Essentials of Pediatric Nursing. China: Lippincott Williams \& Wilkins. pp. 22, 33.

Li, Y., Zhang, W., Liu, J., Arbeit, M. R., Schwartz, S. J., Bowers, E. D., et al. (2011). The role of school engagement in preventing adolescent delinquency and substance use: A survival analysis. Journal of Adolescence, 34(6), 1181-1192. http://dx.doi.org/10.1016/j.adolescence.2011.07.003

Liljeberg, J. F., Eklund, J. M., Fritz, M. V., \& af Klinteberg, B. (2011). Poor school bonding and delinquency over time: Bidirectional effects and sex differences. Journal of Adolescence, 34(1), 1-9. http://dx.doi.org/10.1016/j.adolescence.2010.03.008

Liu, J., \& Wuerker, A. (2005). Biosocial bases of aggressive and violent behavior-implications for nursing studies. International Journal of Nursing Studies, 42, 229-241. http://dx.doi.org/10.1016/j.ijnurstu.2004.06.007

Martin, C. N. (2008). Developmental Pathways towards Delinquency for Female Adolescents: What Can Be Done?. Published Dissertation, School of Human Service Professionals, Widener University. pp. 33-35.

Mathre, M. L. (2006). Alcohol, tobacco, and other drug problems in the community. In Stanhope, M., and Lancaster, J. (Eds.) Foundations of Nursing in the Community; community- oriented practice ( $2^{\text {nd }}$ ed). China: Mosby, Inc. p. 487.

Molnar, B. E., Roberts, A. L., Browne, A., Gardener, H., \& Buka, S. L. (2005). What girls need: recommendations for preventing violence among urban girls in the US. Social Science \& Medicine, 60, 2191-2204. http://dx.doi.org/10.1016/j.socscimed.2004.10.015

Moloney, S. (2010). Focus Groups as Transformative Spiritual Encounters. International Journal of Qualitative Methods, 10(1), 58-72.

Montgomery, K. L., Thompson, S. J., \& Barczyk, A. N. (2011). Individual and relationship factors associated with delinquency among throwaway adolescents. Children and Youth Services Review Journal, 33(7), 1127-1133. http://dx.doi.org/10.1016/j.childyouth.2011.02.005

Nastasi, B. K., \& Schensul, S. L. (2005). Contributions of qualitative research to the validity of intervention research. Journal of School Psychology, 43, 177-195. 
Ou, S., \& Reynolds, A. J. (2010). Childhood predictors of young adult male crime. Children and Youth Services Review, 32(8), 1097-1107. http://dx.doi.org/10.1016/j.childyouth.2010.02.009

Polkinghorne, D. E. (2005). Language and Meaning: Data Collection in Qualitative Research. Journal of Counseling Psychology, 52(2), 137-145.

Rivera-Rivera, L., Allen, B., Thrasher, J. F., Chavez, R., Fernandez-Ortega, C., Galal, O., et al. (2005). Intra-familial physical violence among Mexican and Egyptian youth. Rev Saúde Pública, 39(5), 709-715.

Siu, A. F. (2009). Trait emotional intelligence and its relationships with problem behavior in Hong Kong adolescents. Personality and Individual Differences, 47(6), 553-557. http://dx.doi.org/10.1016/j.paid.2009.05.004

Snethen, G., \& Puymbroeck, M. V. (2008). Girls and physical aggression: Causes, trends, and intervention guided by Social Learning Theory. Aggression and Violent Behavior, 13(5), 346-354. http://dx.doi.org/10.1016/j.avb.2008.05.003

Steketee, M., Junger, M., \& Junger-Tas, J. (2013). Sex Differences in the Predictors of Juvenile Delinquency: Females Are More Susceptible to Poor Environments; Males Are Influenced More by Low Self-Control. Journal of Contemporary Criminal Justice, 29(1), 88-105. http://dx.doi.org/ 10.1177/1043986212470888

Tankersley, V. L. (2006). A Qualitative Examination of Risk Factors Influencing Female Adolescent Delinquency in Dallas County, Texas. A published dissertation presented to the Faculty of the Graduate School, University of Texas at Arlington. p. 155.

Trogdon, S. (2006). Gender Related Differences in Correlations of Juvenile Delinquency in the State of Texas published thesis. pp. 13-14 and 22.

United States Department Of Health and Human Services, Centers for Disease Control and Prevention, \& National Center for Health Statistics. Adolescent health in the United States, 2007. [Online]. 2008 [Cited 2012 Feb 6]; Retrieved from http://www.cdc.gov/nchs/data/misc/adolescent

Ünlü, A., Yildiz, S., \& Şahin, I. (2010). Interaction Between The Cause Of Delinquency And The Sources Of Social Capital. Journal of Entrepreneurship and Development, 5(2), 45-79.

Weijters, G., Scheepers, P., \& Gerris, J. (2009). City and/or Neighborhood Determinants? Studying Contextual Effects on Youth Delinquency. European Journal of Criminology, 6(5), 439-455. http://dx.doi.org/10.1177/1477370809337883

Zahn, M. A., Hawkins, S. R., Chiancone, J., \& Whitworth, A. U. S. Department of Justice, Office of Justice Programs, Office of Juvenile Justice and Delinquency Prevention. The Girls Study Group Charting the Way to Delinquency Prevention for Girls. [Online]. October 2008 [Cited 2011 May 19]; Retrieved from http://www.ncjrs.gov/pdffiles1/ojjdp/223434 